\title{
SIMULATION FOR DAMAGED PARTS RECOGNITION OF SPORTS INJURY BIOLOGICAL IMAGES
}

\author{
SIMULAÇÃO PARA RECONHECIMENTO DE PARTES DANIFICADAS EM IMAGENS BIOLÓGICAS \\ DE LESÕES ESPORTIVAS DE ALTA INTENSIDADE
}

\section{SIMULACIÓN PARA EL RECONOCIMIENTO DE PARTES DAÑADAS EN IMÁGENES BIOLÓGICAS DE LESIONES DEPORTIVAS}

\section{Guozheng Zhu' (iD \\ (Physical Education Professional)}

1. Management Department, Xinke College oF Henan Institute of Science and Technology, Xinxiang, China.

\section{Correspondence:}

Guozheng Zhu

Management Department,

Xinke College oF Henan Institute of Science and Technology, Xinxiang, 453003, China. gym919@163.com

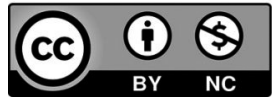

\begin{abstract}
Introduction: To reduce or avoid injuries during high-intensity sports and help treat the injured part, the method of recognizing biological images of the damaged part is a crucial point of current research. Objective: To reduce the damage caused by high-intensity sports and improve the efficiency of injury treatment, this article explores the method of identifying damaged parts in biological imaging of high-intensity sports injuries. Methods: A method is proposed to recognize damaged parts of biological images of high-intensity sports injuries based on an improved regional growth algorithm. Results: A rough segmented image developed in black and white is obtained with the main body as the objective and background. Based on approximate segmentation, the region growth algorithm is used to accurately recognize the damaged region by improving the selection of the hotspots and the growth rules. Conclusion: The recognition accuracy is high, and the recognition time is shorter. The algorithm proposed in this work can improve the precision of recognizing the damaged parts of the biological image of the sports injury and shorten the recognition time. It has the feasibility to determine the damaged parts of sports injuries. Level of evidence Il; Therapeutic studies: investigation of treatment results.
\end{abstract}

Keywords: Sports Injury; Recognition; Exercise,high-intensity.

\section{RESUMO}

Introdução: Para reduzir ou evitar lesões durante esportes de alta intensidade e auxiliar no tratamento da parte lesada, o método de reconhecimento de imagens biológicas da parte lesada é um ponto crucial das pesquisas atuais. Objetivo: Para reduzir os danos causados por esportes de alta intensidade e melhorar a eficiência do tratamento de lesões, este artigo explora o método de identificação de partes danificadas em imagens biológicas de lesões esportivas de alta intensidade. Métodos: é proposto um método para reconhecer partes danificadas de imagens biológicas de lesões esportivas de alta intensidade com base em um algoritmo de crescimento regional aprimorado. Resultados: Uma imagem áspera segmentada desenvolvida em preto e branco é obtida com o corpo principal como objetivo e fundo. Com base na segmentação aproximada, o algoritmo de crescimento da região é usado para reconhecer com precisão a região danificada, melhorando a seleção de pontos quentes e regras de crescimento. Conclusão: a precisão do reconhecimento é alta e o tempo de reconhecimento é menor. O algoritmo proposto neste trabalho pode melhorar a precisão do reconhecimento das partes danificadas da imagem biológica da lesão esportiva e encurtar o tempo de reconhecimento. Tem a viabilidade de determinar as partes danificadas de lesões esportivas. Nível de evidência Il; Estudos terapêuticos: investigação dos resultados do tratamento.

Descritores: Lesões esportivas; Reconhecimento; Exercício, alta intensidade.

\section{RESUMEN}

Introducción: Para reducir o evitar lesiones durante los deportes de alta intensidad y ayudar a tratar la parte lesionada, el método de reconocimiento de imágenes biológicas de la parte dañada es un punto crucial de la investigación actual. Objetivo: Para reducir el daño causado por los deportes de alta intensidad y mejorar la eficiencia del tratamiento de lesiones, este artículo explora el método de identificación de partes dañadas en imágenes biológicas de lesiones deportivas de alta intensidad. Métodos: Se propone un método para reconocer partes dañadas de imágenes biológicas de lesiones deportivas de alta intensidad basado en un algoritmo de crecimiento regional mejorado. Resultados: Se obtiene una imagen segmentada rugosa revelada en blanco y negro con el cuerpo principal como objetivo y fondo. Basado en la segmentación aproximada, el algoritmo de crecimiento de la región se utiliza para reconocer con precisión la región dañada mejorando la selección de los puntos calientes y las reglas de crecimiento. Conclusión: la precisión del reconocimiento es alta y el tiempo de reconocimiento es más corto. El algoritmo propuesto en 
este trabajo puede mejorar la precisión del reconocimiento de las partes dañadas de la imagen biológica de la lesión deportiva y acortar el tiempo de reconocimiento. Tiene la viabilidad de determinar las partes dañadas de las lesiones deportivas. Nivel de evidencia Il; Estudios terapéuticos: investigación de los resultados del tratamiento.

Descriptores: Lesiones deportivas; Reconocimiento; Ejercicio, alta intensidad.

\section{INTRODUCTION}

As a high-intensity exercise, competitive sports, include many forms, such as diving, track and field as well as football. To achieve good results, competitive sports athletes usually need to undergo hard training to improve their physical fitness, project skills, and competitive psychology. Due to the high-intensity training and the difficulty degree of the training program itself, there are many injuries to the athletes. It affects the physical health of the athletes and the athlete's playing career, which has a negative impact on the athletes themselves and the development of the competitive event. ${ }^{1-3}$ To reduce or avoid injury during high-intensity sports and assist in the treatment of the injured part, the method of biological image recognition of the damaged part is a hot spot of current research.

According to the characteristics of damaged regions in biological images after a high-intensity sports injury, this paper uses a method of combining image preprocessing, coarse positioning and damage recognition. And it explores a method for automatic detection and recognition of damaged parts of biological images based on improved region growing algorithm. ${ }^{4-5}$

\section{METHODS}

\section{Preprocessing of sports injury biological image}

Mean filters and median filters of different orders are used to reduce noise to solve the problems of unclear image information and poor segmentation results caused by blurred imaging and unclear edges. ${ }^{6}$ Relying on the image histogram information to transform the gray level of the image, the pixels of each gray level of the biological image can be equalized. The occurrence probability of a pixel that appears less frequently at a certain gray level is enlarged, and the occurrence frequency of a pixel of a certain gray level that originally had a higher probability is lowered. This makes it possible to highlight certain information in the image while suppressing some unwanted information. The transformation function for homogenization is shown below.

$$
S_{k}=T\left[r_{k}\right]=\sum_{j=0}^{k} P_{r}\left(r_{j}\right)=\sum_{j=0}^{k} \frac{n_{j}}{N}
$$

$$
r_{k}=T^{-1}\left[S_{k}\right]
$$

$$
P_{k}\left(\mathrm{r}_{\mathrm{k}}\right)=\frac{n_{k}}{N}
$$

Where:T represents the threshold, and $\mathrm{N}$ represents the total number of pixels in the image. Assuming there are $L$ gray levels, the number of occurrences of the $k$-th gray level $r k$ is $n k, 0 \leq n k \leq 1, k=0,1 \ldots, L-1$. $P$ represents the probability of occurrence of the k-th gray level. Linear discriminant analysis is performed on the basis of the equalization process so that the processed image is transformed into higher or lower gray values, and the various tissue images are distinguished more clearly. Finally, the commonly used Canny operator edge detection algorithm is used to preprocess the damaged image. The edge information of the image is concentrated in the high-frequency region of the image. Sharpening or edge detection is performed on the image. The essence is to perform high-frequency filtering. It is completed by the following 4 steps: (1) applying Gaussian filtering to smooth the image and remove noise; (2) calculating the gradient intensity and direction of the image; (3) the width of the edge is 1-pixel point as much as possible by non-maximum suppression; (4) using the method of double threshold to determine possible boundaries. ${ }^{8}$ The rough contour region of the damaged image is obtained through preprocessing. Then, the image can be coarsely segmented by combining the Snake model and adaptive thresholding. The image can be further recognized by the improved region growing algorithm.

\section{Coarse segmentation of Damaged Image Based on Snake Model and Adaptive Thresholding}

Before recognizing the damaged part of a high-intensity sports injury biological image, the contour of the damaged part needs to be extracted first. Based on the characteristics of the damaged image, a method combining the Snake model and adaptive thresholding is proposed to obtain the contour of the damaged part.

The Snake model is often used for contour extraction of irregularly shaped medical images. It mainly uses active contour lines in mechanics to continuously deform and approach the target boundary under the combination of internal image energy and external image energy. At a certain point, the energy value is the smallest, and the equilibrium is reached. At this time, the contour curve with the smallest energy is obtained, and the movement is stopped to obtain the target contour. ${ }^{9}$ The energy function Esnake of the Snake model parameter curve S can be expressed as shown below.

$$
E_{\text {snake }}(s)=\frac{1}{2} \int_{0}^{1} \alpha(s)\left|\frac{\partial V}{\partial s}\right|+\beta(\mathrm{s})\left|\frac{\partial^{2} V}{\partial s^{2}}\right| d s+\int_{0}^{1} \varepsilon(V(s)) d s
$$

In equation (4), the first term represents the internal energy of the broken contour curve, and the second term represents the external energy. It can be defined as $V(s)=(x(s), y(s)), s \in[0,1]$. The $s$ represents the arc length. The $x(s)$ and $y(s)$ represent the coordinates of the active contour line in the image. And the $a$ and $\beta$ represent the weighted value, which can affect the size of internal energy and external energy. Under the action of internal and external forces, the curve moves towards the target contour and finally converges to the target contour to complete the image segmentation. After obtaining the contour of the damaged part, combined with the adaptive threshold segmentation, the image can be segmented conveniently and quickly. The iterative method is adopted for calculating the adaptive threshold. The calculation method is shown below.

1. A proper threshold is selected as the initial estimate $T$.

2. $T$ is used for image segmentation to generate two sets of pixels: $G 0$ is composed of all pixels whose gray value is less than or equal to $T ; G 1$ is composed of all pixels whose gray value is greater than $T$. 
3. The average gray values $\mathrm{m} 0$ and $\mathrm{m} 1$ of the pixels in $\mathrm{G} 0$ and $\mathrm{G} 1$ are calculated respectively.

4. A new threshold is calculated.

$$
T=\frac{1}{2}\left(\mathrm{~m}_{0}+\mathrm{m}_{1}\right)
$$

5. Steps 2 to 4 are repeated until T converges after iteration (setting a $\Delta T$, when $T n-T n-1$ is less than $\Delta T, T$ has converged).

According to this method, the injury images of 80 athletes in a sports college were segmented and iteratively calculated. Several of them were selected as symbolic data and results, as shown in Table 1.

Through the analysis, when the selected-area threshold $\mathrm{T}$ is greater than 200, the thresholds after iterative calculation are roughly floating around 220. After selecting a proper threshold T, the grayscale of pixels less than $\mathrm{T}$ in the image is converted to 0 , and the grayscale of pixels greater than or equal to T in the image is converted to 1. Then, the image is transformed into a binary image. The black and white development in the image clearly separates the image into two parts: the target and the background.

\section{Recognition of Damaged Parts of Injury Image Based on Improved Region Growing Algorithm}

After the above method, it is still unable to accurately recognize the damaged part of the sports injury biological image. Therefore, this paper uses the improved region growing algorithm to further recognize the damaged part and obtain the precise contour of the damaged area.

The core idea of the region growing algorithm is the growth rules, termination rules, and selection methods of seed points. The algorithm is selecting one or more seed points based on a certain method and starting to grow according to the growth rules based on the location of the seed points. It stops growing when the termination rule is met. The selection of seed points and the setting of growth rules in the region growing are important. Therefore, this paper proposes to improve the region growth rules. First, the growing threshold $T$ is set as 0 , and the region growing algorithm is used to fuse pixels with the same gray level as the seed point. Then, a new growing threshold $\mathrm{T}$ is set. The starting point of the growth is a 3rd or 5th order matrix with the seed point as the initial growing region. When deciding whether to fuse the domain pixels, it can use the average gray value of the initial growing region and

Table 1. Iterative test data and results.

\begin{tabular}{c|c|c|c}
\hline Image & $\mathbf{T 0}$ & $\boldsymbol{\Delta} \mathbf{T}$ & Calculation result T \\
\hline 19 & 230 & 10 & 209.42 \\
\hline 34 & 200 & 10 & 223.81 \\
\hline 76 & 220 & 10 & 219.45 \\
\hline 81 & 240 & 10 & 206.13 \\
\hline
\end{tabular}
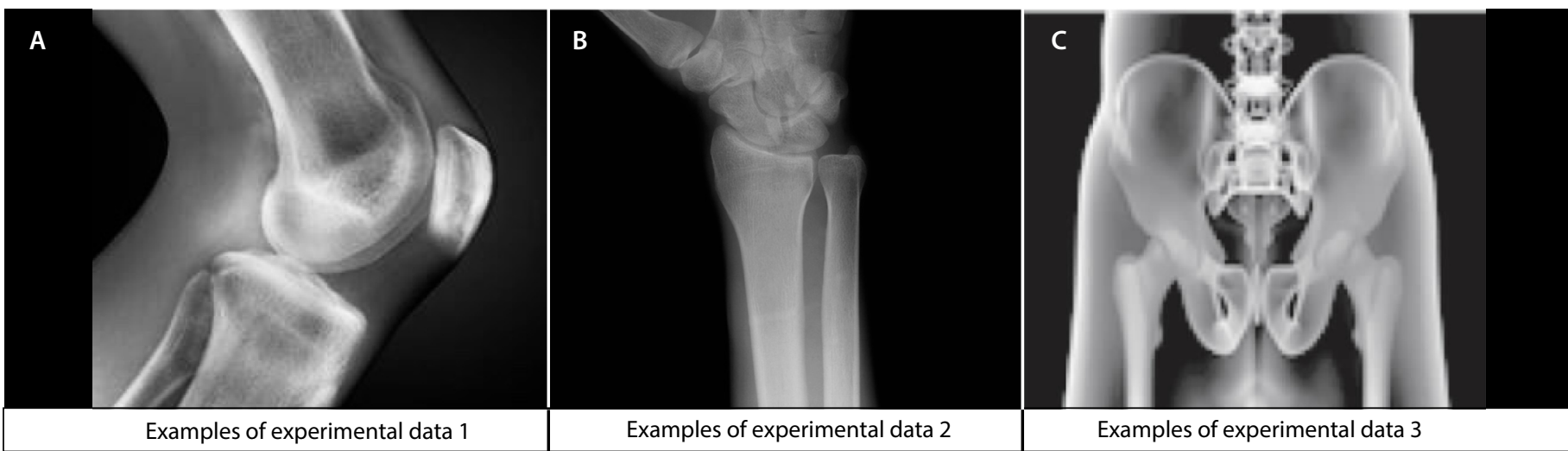

Figure 1. Examples of some experimental data.

the domain point to find the gray difference. If the gray value y of the current point meets the following, the pixels are merged.

$$
|y-\bar{X}| \leq T
$$

After merging the first circle of domain points, the average gray value of the new growing region is calculated again. The calculation method of the regional average grayscale is shown below.

$$
\bar{X}=\frac{1}{M} \sum_{Q} f(x, y)
$$

Where: $M$ represents the number of pixels. Q represents the seed point domain. The $f(x, y)$ represents the gray value of $(x, y)$. $\bar{x}$ represents the regional average gray value of calculation output. An average grayscale difference for each domain is calculated, and the domains with the smallest average grayscale differences are merged.

\section{RESULTS}

\section{Experimental recognition results}

To verify the overall performance of the method for recognizing damaged parts of high-intensity sports injury biological images based on the improved region growing algorithm, an experimental model was established using the Matlab tool. 80 athletes of a certain sports college are taken as experimental subjects, and the details are shown in Table 2.

The data of each body part, the training samples, and the image samples to be identified of the subjects are collected using relevant instruments. They are input to the established model, and the results are output. Some of the images are processed through preprocessing, Snake model, coarse segmentation of adaptive thresholding, and improved region growing algorithm. The results are shown in Figure 1.

\section{Comparison of recognition rates of different recognition methods}

According to the algorithm proposed in this paper and the experimental data output by the above model, the recognition rate is used as an index to verify the method of recognizing the damaged parts of high-intensity sports injury biological images based on the improved region growing algorithm. The results are shown in Figure 2.

Table 2. The details of experimental subjects

\begin{tabular}{c|c}
\hline Projects & Remarks \\
\hline Men & 59 \\
\hline Female & 21 \\
\hline Height/cm & $164-188$ \\
\hline Weight/kg & $48-71$ \\
\hline Training program & $\begin{array}{c}\text { Basketball, football, table tennis, javelin, long distance } \\
\text { running, short-distance run, long jump, high jump etc. }\end{array}$ \\
\hline
\end{tabular}




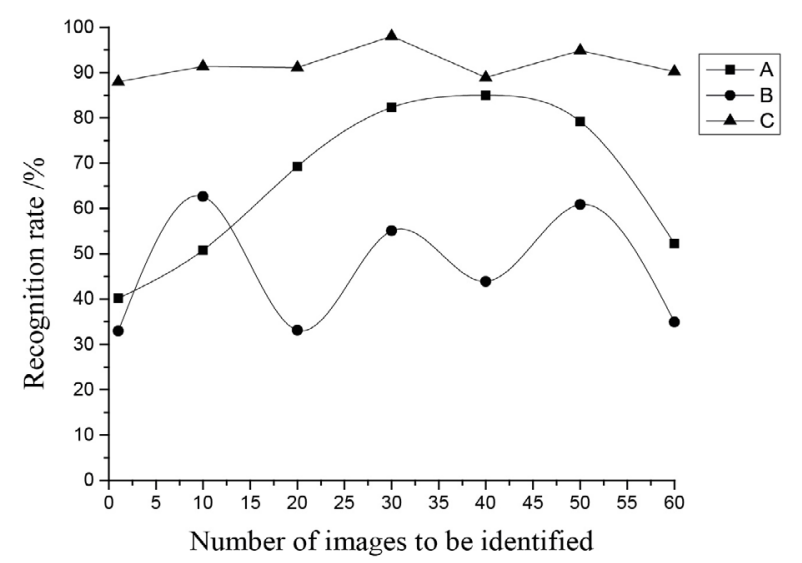

Figure 2. Comparison of recognition rates of different methods.

\section{DISCUSSION}

As can be seen from Figure 1, the method proposed in this paper can more accurately recognize the damaged image. The image damage recognition rate of the three methods can be obtained from Figure 2. The recognition rate curve of the multi-modal medical image damage detection method based on the discrete wavelet transform is developed in an inverted $U$ shape, and the recognition rate is low overall. The recognition rate curve of the treatment position of X-ray image based on the parallel convolution neural network algorithm has a large fluctuation, indicating that the method is not feasible. The recognition rate of the high-intensity sports injury biological image recognition method based on the improved region growing algorithm proposed in this paper is significantly higher than other traditional methods. Before identifying the damaged part, this method effectively reduces the recognition time by converting the grayscale of the image. The above experimental results prove that the proposed method has strong practicality and robustness.

\section{CONCLUSION}

To effectively improve the recognition efficiency of damaged parts of high-intensity sports injury biological images, this paper uses the average filter and the median filter to reduce noise according to the characteristics of the damaged image. The method proposed in this paper has advantages in both recognition rate and recognition efficiency, indicating that the method can provide a strong basis and support for research in this field.

The author declare no potential conflict of interest related to this article

AUTHORS' CONTRIBUTIONS: The author made significant contributions to this manuscript. Guozheng Zhu: writing and performing surgeries; data analysis and performing surgeries; article review and intellectual concept of the article.

\section{REFERENCE}

1. Pan SN, Lyu XH, Liu Q, Guo QY. Pay attention to the imaging study of sport injury and illness in winter olympics sports. Chin Med J (Engl). 2018;131(9):1013-5.

2. Kim JS, Park HS, Oh SS. An analysis of the characteristics of sports activities and injury experiences of leisure sports participants. J Exerc Rehabil. 2018;14(3):407-12.

3. Liu S. Study on medical image enhancement based on wavelet transform fusion algorithm. J Med Imaging Health Inf. 2017;7(2);388-92.

4. Guo L, He H, Wang $Y$, Wang $C$, Yang $X$, Liu L. [Using parallel convolutional neural networks for treatment position recognition in X-ray images]. Zhongguo Yi Liao Qi Xie Za Zhi. 2018;42(2): 92-94. Chinese.

5. Zareie M, Parsaei H, Amiri S, Awan MS, Ghofrani M. Automatic segmentation of vertebrae in 3DCT images using adaptive fast 3D pulse coupled neural networks. Australas Phys Eng Sci Med. 2018;41(4):1009-20

6. Jin Y, Xia K. Intelligent location and recognition mechanism of abnormal point of medical image based on reliable transmission in medial CT scanner local big data networks. J Med Imaging Health Inf. 2018; 8(3);609-17.

7. De Neve J,Thas O, Gerds TA. Semiparametric linear transformation models: Effect measures, estimators, and applications. Stat Med. 2019;38(8):1484-501.

8. Zhang Z, Song R, Liu H. Edge connection based Canny edge detection algorithm. Pattern Recognition and Image Analysis. 2017;27(4);740-7.

9. Wang Z, Wang S, Sun Y. A new phase unwrapping algorithm based on the GVF-Snake model of edge detection. J China Univ of Min Tech. 2017;46(6):1394-401. 